\title{
High resolution chromosomal microarray analysis in paediatric obsessive-compulsive disorder
}

Edna Grünblatt ${ }^{1,2,3,4,8^{*}+}$ (D), Beatrice Oneda ${ }^{5+}$, Arif B. Ekici ${ }^{7}$, Juliane Ball ${ }^{1}$, Julia Geissler ${ }^{6}$, Steffen Uebe ${ }^{7}$, Marcel Romanos ${ }^{6}$, Anita Rauch ${ }^{2,4,5+}$ and Susanne Walitza ${ }^{1,2,4^{*+}}$

\begin{abstract}
Background: Obsessive-Compulsive Disorder (OCD) is a common and chronic disorder in which a person has uncontrollable, reoccurring thoughts and behaviours. It is a complex genetic condition and, in case of early onset (EO), the patients manifest a more severe phenotype, and an increased heritability. Large ( $>500 \mathrm{~kb}$ ) copy number variations (CNVs) previously associated with autism and schizophrenia have been reported in OCD. Recently, rare CNVs smaller than $500 \mathrm{~kb}$ overlapping risk loci for other neurodevelopmental conditions have also been reported in OCD, stressing the importance of examining CNVs of any size range. The aim of this study was to further investigate the role of rare and small CNVs in the aetiology of EO-OCD.
\end{abstract}

Methods: We performed high-resolution chromosomal microarray analysis in 121 paediatric OCD patients and in 124 random controls to identify rare CNVs (>50 kb) which might contribute to EO-OCD.

Results: The frequencies and the size of the observed rare CNVs in the patients did not differ from the controls. However, we observed a significantly higher frequency of rare CNVs affecting brain related genes, especially deletions, in the patients $(\mathrm{OR}=1.98,95 \% \mathrm{Cl} 1.02-3.84 ; \mathrm{OR}=3.61,95 \% \mathrm{Cl} 1.14-11.41$, respectively). Similarly, enrichment-analysis of CNVs gene content, performed with three independent methods, confirmed significant clustering of predefined genes involved in synaptic/brain related functional pathways in the patients but not in the controls. In two patients we detected de-novo CNVs encompassing genes previously associated with different neurodevelopmental disorders (NRXN1, ANKS1B, UHRF1BP1).

Conclusions: Our results further strengthen the role of small rare CNVs, particularly deletions, as susceptibility factors for paediatric OCD.

Keywords: $\mathrm{OCD}, \mathrm{CNV}$, Enrichment analysis, De-novo, Early-onset

\section{Background}

Obsessive-compulsive disorder (OCD) is characterized by distressing, intrusive obsessive thoughts and/or repetitive compulsive behaviours [1]. According to a survey of adult US citizens, OCD is a frequent psychiatric disorder with $2.3 \%$ of respondents meeting full OCD DSM-IV criteria for lifetime and $1.2 \%$ for 12-month prevalence [2]. Similar

\footnotetext{
* Correspondence: edna.gruenblatt@kjpd.uzh.ch; susanne.walitza@puk.zh.ch Edna Grünblatt and Beatrice Oneda are equal first authors

${ }^{\dagger}$ Equal contributors

'Department of Child and Adolescent Psychiatry and Psychotherapy,

University Hospital of Psychiatry Zurich, University of Zurich, Neumünsterallee

9, 8032 Zürich, Switzerland

Full list of author information is available at the end of the article
}

prevalence rates of 0.1 to $2.3 \%$ have been reported in European countries [3]. In up to $50 \%$ of the cases, OCD emerges already during childhood or adolescence [4], and a bimodal age of onset, during early puberty or in the early twenties [5], has been described. The definition of "earlyonset" OCD (EO-OCD) differs among studies regarding the cut-off for age of onset; below 7 years of age was the lowest and under 18 years of age was the highest cut-off age, which thus marks the "minimal" consensus for definition criteria. Accordingly, patients with "late onset" (LO) must be older than 18 years at onset. EO-OCD may represent a more severe or more "biological" subtype of the disorder in comparison to LO [6], with an increased 
heritability as well as differences in gender distribution, symptomatology, and comorbidity. In addition, in OCD with early and childhood onset, triggering life events seem to be observed to a lesser extent $[2,7]$. Therefore, it has been hypothesized that EO-OCD represents a specific highly heritable subtype of OCD [8].

Despite the strong heritability estimates between 40 and 80\% [9-11], two recent genome-wide studies [12, 13] failed to detect association of common single nucleotide polymorphisms (SNPs) with OCD. However, in a metaanalysis [14] an association between OCD and polymorphisms in the serotonin-related genes (5-HTTLPR/ SLC6A4 and HTR2A) and in the catecholamine modulation genes (COMT and $M A O A)$ have been reported. Similarly, we showed for the first time the association of 5-HTTLPR polymorphisms with EO-OCD $[15,16]$ as well as association to HTR2A polymorphism [17].

In order to further explain the heritability, it has been suggested that copy number variations (CNVs) play an important role in neurodevelopmental disorders [18-20]. There is rising awareness that common variants may explain a relatively small amount of common diseases, while rare variants with relatively large functional effects may add up to a significant disease contribution [21].

Up to now, five CNV studies in patients with OCD have been conducted [22-26]. The first study assessed the recurrent 15q11-q13 Prader-Willi syndrome and the 22q11.2 DiGeorge syndrome regions [22] in adults with OCD, since both disorders are often accompanied by OCD symptoms. However, in 236 OCD-patients no CNVs affecting the two regions were detected [22]. In a study, conducted by our group, an association between a $\sim 100$ base pairs (bp) deletion in the HTR2A promoter region and paediatric EO-OCD [23], as well as increased OCD-severity and an earlier age-of-onset, were reported. Recently, the first genome-wide analysis in a cohort of 1613 OCD and 1086 Tourette syndrome (TS) patients was performed. The study focused on CNVs larger than $500 \mathrm{~kb}$ and revealed aberrations in 16p13.11, 22q11.21 and in 6q25.2-q27 [24]. Additionally, a study on CNVs smaller than $500 \mathrm{~kb}$ screened 16 adults with EO-OCD and 12 controls [25] and a rare intragenic FMN1 microdeletion in $15 \mathrm{q} 13.3$ was detected. In a very recent study 307 EO-OCD (259 of European ancestry) have been investigated for small and rare CNVs [26]. Interestingly, the authors found CNVs in genes involved in neuronal migration, synapse formation and postsynaptic scaffolding, which might be relevant to the pathogenesis of OCD. Four cases had CNVs involving known genomic disorder loci (1q21.1, 15q11.2-q13.1, 16p13.11 and 17p12). [26].

In light of these current findings and the notion of a stronger genetic contribution in patients with EO-OCD, we conducted a genome-wide CNVs analysis, using high- resolution chromosomal microarray analysis (CMA) in 121 homogenous phenotyped paediatric EO-OCD patients.

\section{Methods \\ Paediatric patients with OCD}

121 paediatric patients with EO-OCD were recruited from the Departments of Child and Adolescent Psychiatry at the University of Würzburg, Germany and the University of Zürich, Switzerland (all Caucasian). The mean age \pm SD of the patients was $12.99 \pm 2.8$; mean age of onset $=10.43$ \pm 3.2 ; 75 were males and 46 females. Although an EOOCD sample could in principle also consist of adult patients with a retrospectively analysed onset, the present study includes only paediatric patients that guaranteed an early-onset of the disorder.

All patients fulfilled the diagnostic criteria for OCD according to the Diagnostic and Statistical Manual of Mental Disorders, 4th edition (DSM-IV) [27] and the International Statistical Classification of Diseases and Related Health Problems, 10th Revision (ICD-10) [28]. Patients and parents from Würzburg were interviewed separately by senior clinicians with a semi-structured diagnostic interview of psychiatric disorders in children and adolescents (Kinder-DIPS; children and parents version) [29]. The patients and parents of Zürich underwent the German version of a semi-structured clinical interview (KSADS-PL) [30] to investigate their phenotype, including psychiatric comorbidities. Autistic spectrum disorders were screened within an ascertainment for psychopathology (CASCAP-D) [31].

The Children's Yale Brown Obsessive Compulsive Scale (CY-BOCS) [32] was used in all patients to assess severity and characteristics of OCD symptomatology. A summary score above 16 points was determined to be the cut-off for clinical impairment caused by OCD. In the present patients' sample, the mean CY-BOCS score was 22.1, SD =6.98. The DSM-IV and DSM-5 [1] do not require children to fulfil the criterion of insight into the irrationality of their symptoms. Therefore, it is possible that the CY-BOCS scores underestimated the severity of OCD in cases of reduced insight into the disorder. For the assessments of TS and tic-disorders, the German version [33] of the Child and Adult Schedule for Tourette and Other Behavioural Syndromes (STOBS) [34] was used in the Würzburg patients, the Yale Global Tic Severity Scale (YGTSS) [35] in the Zürich patients.

Patients with comorbid disorders $(n=75 / 121)$ were included in the study when the OCD was the primary diagnosis, as assessed by two senior clinicians independently (see Additional file 1: Table S1).

Exclusion criteria were: lifetime history of psychotic disorders, Tourette's disorder (TS), autistic spectrum disorder (ASD), alcohol dependence, intellectual disability (ID; IQ < 70). IQ was assessed by the Wechsler Intelligence 
Scale (WISC) [36] in the majority of cases (over 85\%) while in few cases (less than 15\%) the IQ was assessed by Culture Fair Intelligence Test (CFT) [37]. Since IQ $<70$ was used only for exclusion criteria to avoid inclusion of any ID probands, using two scales do not affect the paediatric OCD population selection. Mean IQ score in our patient cohort was 108.27 ( $\mathrm{SD}=13.29)$.

The study was approved by the respective local ethics committees with the latest version of the Declaration of Helsinki, including an ethical permission granted by the Ethic Committees from Würzburg and the Cantonal Ethic Commission of Zürich (Ref. Nr. 39/97, 140/3 and EK: KEK-ZH-Nr. 2010-0340/3) and written informed consent was obtained in all cases from the participants or/and their parents.

\section{Control sample for statistical comparison}

We analysed the data of 124 random population samples of Caucasian origin (DNA was extracted from native tissue), recruited at the Institute of Medical Genetics, University of Zurich, in the same manner, on the Cytoscan HD Array as the patient samples (76 males and 48 females, $X^{2}=0.012$, $p>0.999$ compared to EO-OCD).

\section{DNA extraction and chromosomal microarray analysis (CMA)}

Constitutional genomic DNA was extracted from whole blood (EDTA-tubes; $n=74$ cases and family) with the desalting Proteinase K methodology [38] or from saliva samples (Oragene DNA, DNA Genotek Inc., Ontario, Canada; $n=47$ cases and family) using the manufacturer's protocol. To assess genomic DNA purity, the ratio of absorbance at $260 \mathrm{~nm}$ and $280 \mathrm{~nm}$ was used. 74/ 121 cases were part of the previous reported genomewide CNV ( $>500 \mathrm{~kb})$ analysis [24], in which only one large $\mathrm{CNV}$ was reported and confirmed in the current study (patient \#9025079001 7q21.11 deletion), without any previous findings that were not confirmed in the current study. DNA from available parents and/or siblings of 30 patients was investigated consecutively due to $\mathrm{CNV}$ findings in the patients.

DNA was analysed with the Cytoscan HD Array (containing about 750,000 SNPs and 1.9 million nonpolymorphic probes) (Affymetrix Inc., Santa Clara, CA, USA) at a genome-wide resolution of $50 \mathrm{~kb}$ for both duplications and deletions. We have chosen this resolution in order to minimize the possibility of false positive CNVs, which according to our previous assessment have a median size of $19 \mathrm{~kb}$ [20]. Array hybridization and quality control was performed according to the manufacturer's protocol. Data were analysed with Chromosome Analysis Suite (ChAS) software (Affymetrix) for changes of relative intensities. The CNV analysis was based on build 32.1. Genomic coordinates are based on GRCh37/hg19. In order to exclude common benign CNVs, we used a reference set of 820 in-house healthy controls and 1038 Affymetrix controls in combination with the Database of Genomic Variants (DGV) from the Centre for Applied Genomics (February 2009, hg19).

$\mathrm{CNVs}$ including coding sequences of genes that were absent in our in-house and Affymetrix primary control cohort and either unreported or reported only from limited sources in the DGV database were defined as rare CNVs in both the EO-OCD and the random control cohorts and used for statistical comparison.

\section{Statistical analysis and enrichment analysis}

Frequency analysis was conducted using $\mathrm{X}^{2}$ test and the power was calculated using G*Power v.3.1.9.2 [39]. For continuous measures, the two-tailed $\mathrm{t}$-test was used.

The genes within the rare CNVs identified in the patients and controls were investigated for their enrichment in pathways and functional groups using the Enrichment Analysis of Selected Entities (EASE) tool, based on Gene Set Enrichment Analysis (GSEA) method $[40,41]$, with the Pathway Studio software v.11.2.04 (Elsevier; Mammal database). Significant enriched pathways were considered with $p<0.005$. As additional validation, we used the Database for Annotation, Visualization and Integration Discovery (DAVID) [42] for functional annotation clustering. The genes within CNVs were entered using the identifier "Official_gene_symbol" to create gene lists for EO-OCD and for control samples. We reported clusters with enrichment score $>1.3$ as suggested by Huang da W et al. [42]. Significant enriched pathways were considered with $p<$ 0.05 following Bonferroni, Benjamini and FDR corrections. In addition, as a third confirmation analysis, we performed a CNV enrichment analysis using PLINK [43] version 1.07 and its -cnv-enrichment-test option on all CNVs called [44]. Following multiple testing correction (6 tests) $p<0.008$ was considered as significant, and nominal significant for $p<0.05$.

Statistical analysis was performed with SPSS v.21 (IBM) and StatView v.5.0 (SAS Inst.). The level of significance was alpha $=0.05$.

\section{Results}

We detected rare CNVs (mean size $=258 \pm 308 \mathrm{~kb}$, min. $50 \mathrm{~kb}$ max. $1500 \mathrm{~kb}$ ) in 41 out of 121 patients (Table 1; for details see Additional file 2: Table S2a) and in 39 out of 124 controls (mean size $=274 \pm 234 \mathrm{~kb}$, min. $50 \mathrm{~kb}$ max. $1027 \mathrm{~kb}$; for details see Additional file 2: Table $\mathrm{S} 2 \mathrm{~b})$. There was no significant difference in the number of all detected rare CNVs between patients $(n=41 / 121$; $34 \%)$ and controls $\left(n=39 / 124 ; 31 \% ; X^{2}=0.165, p=\right.$ $0.685)$ nor in the CNVs' size $(\mathrm{t}(-74.47)=0.255, p=0.8)$. Moreover, no significant difference was observed in IQ 


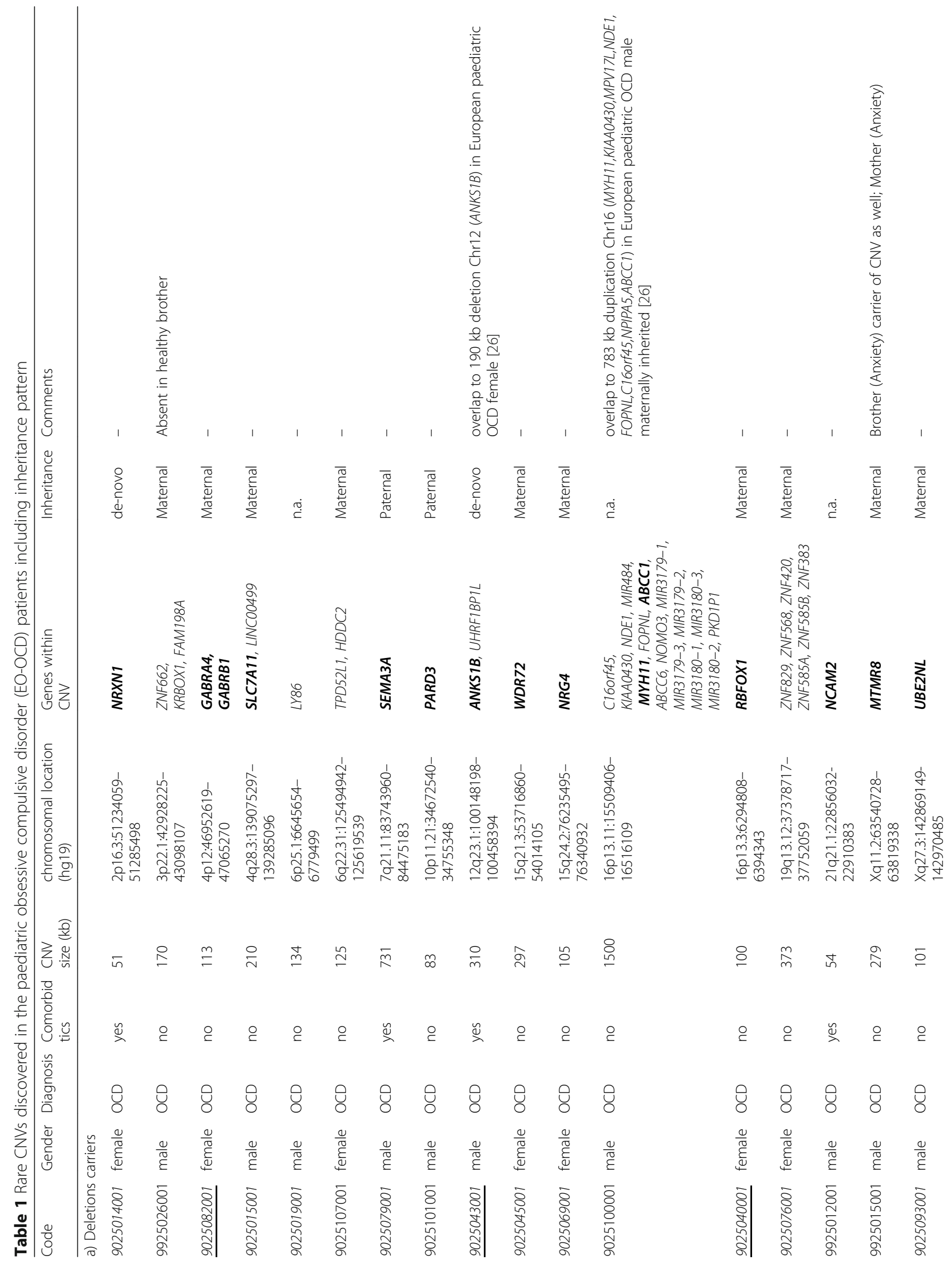




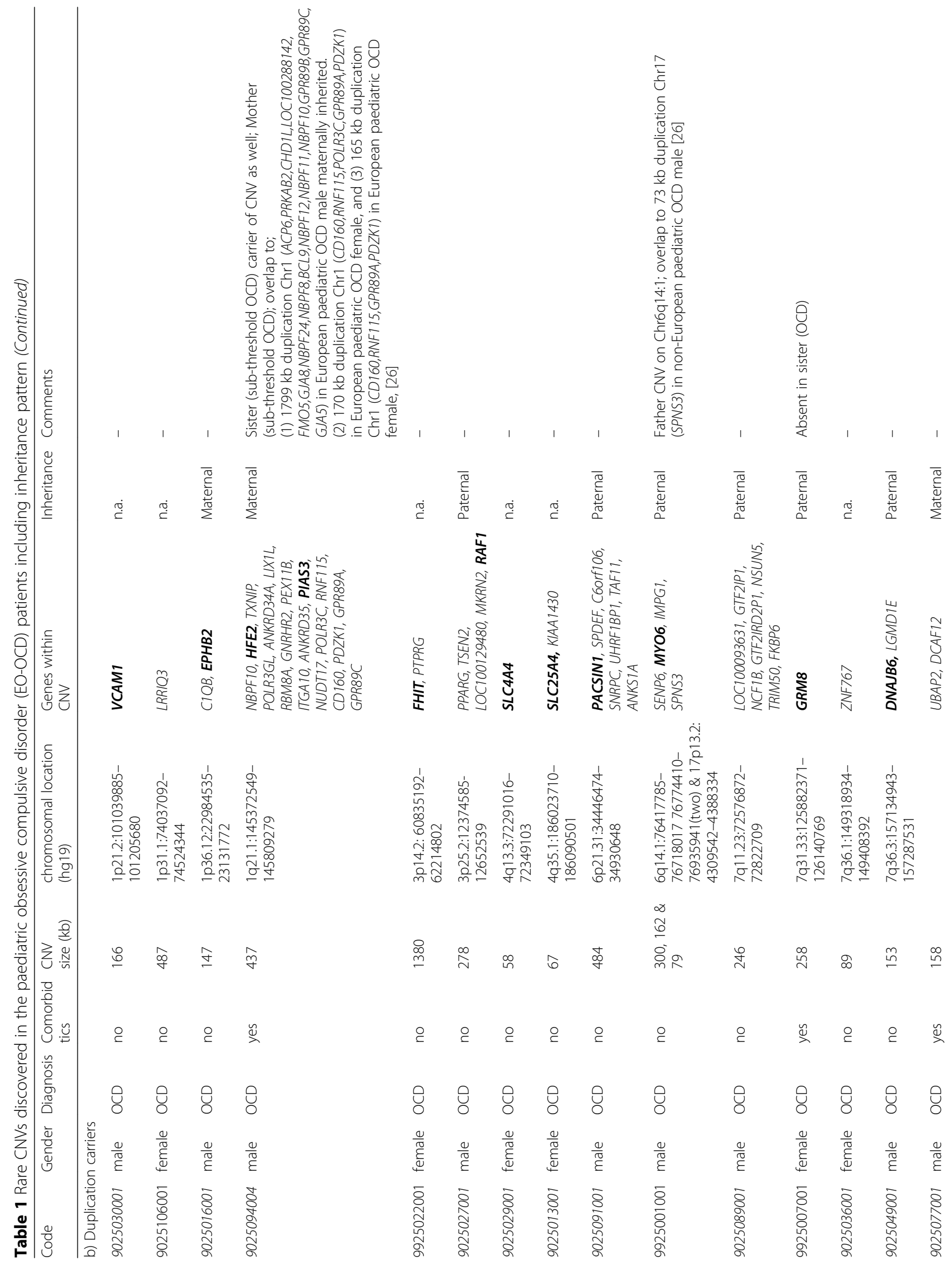




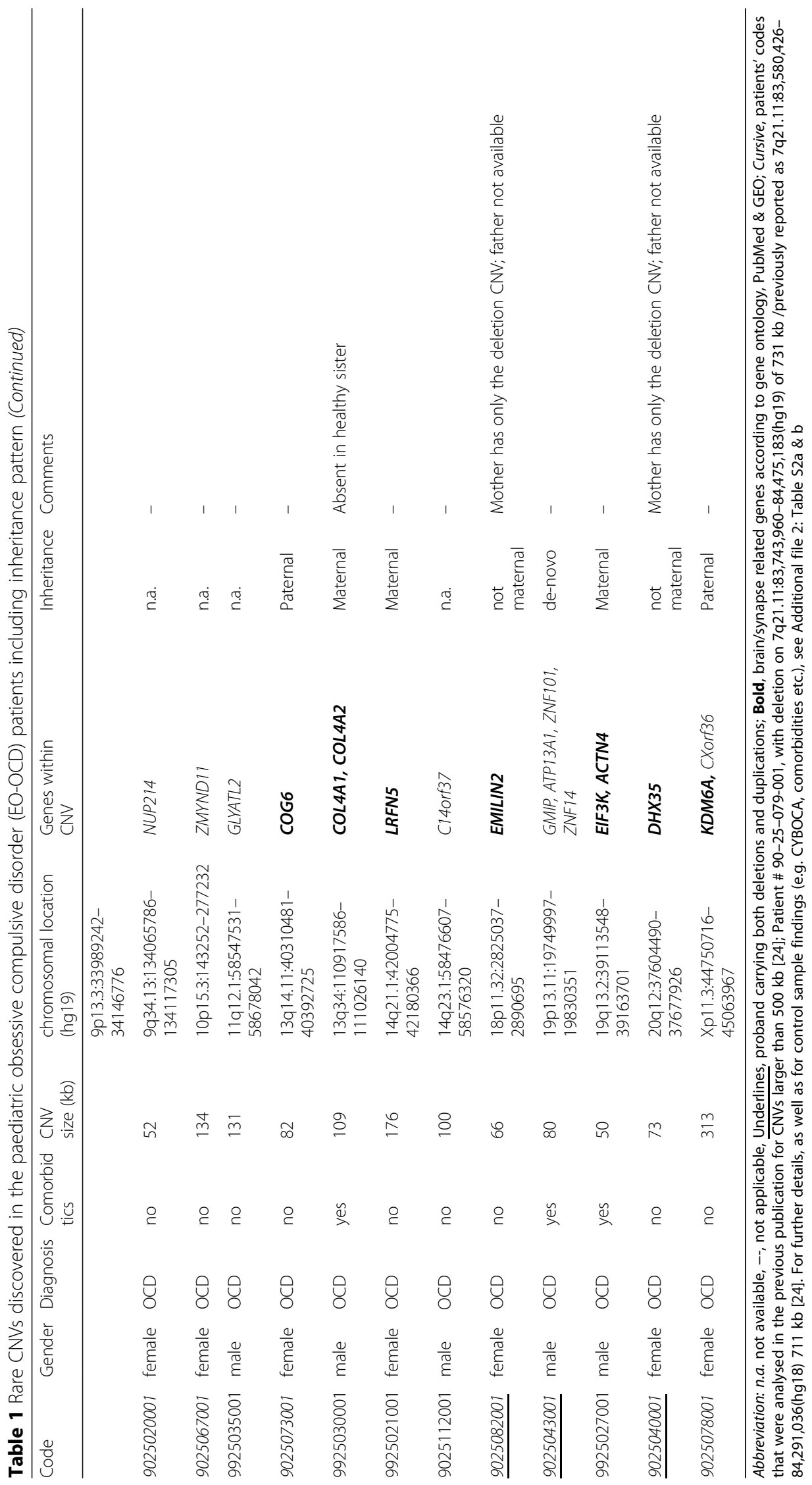


scores or OCD severity (measured with CY-BOCS) between carriers and non-carriers of rare CNVs.

However, we observed a significantly higher number of $\mathrm{CNV}$ carrying brain/synaptic genes in the patients in comparison to the controls $\left(\mathrm{X}^{2}=4.225, p=0.0398\right.$; odds ratio $(\mathrm{OR})=1.98,95 \%$ CI 1.02-3.84; Power $1-\beta=0.858)$. In particular, the number of rare deletion carrying brain/ synaptic genes was significantly higher in patients $(n=$ 13 vs. 108 non-carriers) compared to controls $(n=4$ vs. 120 non-carriers; $\mathrm{X}^{2}=5.360, p=0.021 ; \mathrm{OR}=3.611,95 \%$ CI 1.14-11.41; Power 1- $\beta=0.8909$ ).

In line with this finding, both enrichment cluster analyses (Pathway Studio and DAVID), revealed a higher number of synaptic and brain related functional pathways in the patients (10 brain/synapse clusters, 103 none brain/ synapse clusters in Pathway studio; 6 brain/synapse clusters, 31 none brain/synapse clusters in DAVID) in comparison to the controls (2 brain/synapse clusters, 98 none brain/synapse clusters in Pathway studio; 0 brain/synapse clusters, 25 none brain/synapse clusters in DAVID; $\mathrm{X}^{2}=$ 4.682, $p=0.03$ for Pathway Studio; $\mathrm{X}^{2}=4.488, p=0.033$ for DAVID Additional file 3: Table S3a \& b).

Both enrichment cluster analyses resulted in similar top clusters for the patients group (KRAB domain, zinc-finger protein family) and for the control group (serum amyloid A, high-density lipoprotein), confirming the integrity of both analyses. The most significant $(p<0.0001)$ GO functional group enrichment cluster in the patient cohort belong to: axon guidance (genes within the CNVs: RAF1, EPHB2, MYH11, SEMA3A, ITGA10, HFE2, NRXN1, COL4A1, COL4A2), axonal fasciculation (genes within the CNVs: EPHB2, NCAM2, SEMA3A), synapse (genes within the CNVs: EPHB2, GABRA4, GABRB1, NRXN1, MYO6, PIAS3, ANKS1B, PACSIN1) and neuron cell-cell adhesion (genes within the CNVs: NCAM2, NRXN1), as analysed by Pathway Studio (for details see Additional file 3: Table S3a). Similarly, DAVID analysis revealed in the patients several GO related to synaptic and brain related genes, like in cluster 5: axonogenesis, cell morphogenesis involved in neuron differentiation, and neuron projection morphogenesis (gene cluster: NCAM2, PARD3, NRXN1, SEMA3A, EPHB2) (for details see Additional file 3: Table S3b). Interestingly, the control group did not show any synaptic or brain related clusters when the DAVID software was used, while only 2 clusters $(p<0.005)$ were found using Pathway Studio analysis: catecholamine metabolic process (genes within the CNVs: SULT1A3, SULT1A4) and axonal fasciculation (genes within the CNVs: CNTN4, NRCAM; for details see Additional file 3: Table S3a).

We could further confirm a significant enrichment $\left(p=1.28 \times 10^{-3}\right)$ of CNVs in brain expressed genes by applying the PLINK enrichment analysis [44]. Notably, there was no significance for the enrichment analysis for overall genes. The significance threshold was $8.33 \times 10^{-3}(0.05 / 6$, because 6 tests were performed) (Additional file 4: Table S4).

Where possible, the heritability of rare CNVs was assessed by analysing the parents/siblings of the index patients. We detected two de-novo CNVs in two patients with EO-OCD (one male and one female), both of whom had a comorbid tic disorder (Table1 \& Additional file 2: Table S2a). Twenty-six patients inherited the CNVs (16 from the mother and 10 from the father). In two additional patients (9025100001 \& 9925022001) CNVs were not maternally inherited (paternal DNA was unavailable). Three patients carried CNVs located on the $\mathrm{X}$-chromosome: two deletions (affecting the genes $U B E 2 N L$ and MTMR8) and one duplication (affecting the genes KDM6A and CXorf36). Interestingly, both deletions are hemizygous aberrations.

\section{Discussion}

We did not detect a higher number of rare CNVs in paediatric patients with EO-OCD compared to controls, which is in line with previous publications [24, 26]. However, cluster analyses of the gene content of the rare $\mathrm{CNVs}$ revealed a significantly higher number of genes involved in synaptic and brain related pathways in the cases compared to controls, similarly to previous findings $[24,26]$. Our results, therefore, further support the hypothesis that the aetiopathology of EO-OCD may be related to neurodevelopmental processes $[9,45]$. In addition, we demonstrate that the OR of $3.6(p=0.021)$ for EO-OCD in carriers of rare small deletions is in the same range as that reported previously for larger deletions ( $\mathrm{OR}=4.4, p=0.04)$ [24]. Therefore, as Gazzellone et al. [26] recently postulated, not only large CNVs $>500 \mathrm{~kb}$ but also smaller rare CNVs $(\geq 50 \mathrm{~kb})$, particularly deletions in brain related genes, might represent a risk factor for paediatric EO-OCD.

We observed two large deletions $(>500 \mathrm{~Kb})$ in our cohort. The first one was a $1.5 \mathrm{Mb}$ deletion in $16 \mathrm{p} 13.11$ with undeterminable inheritance in a male patient. The second was a $731 \mathrm{~kb}$ deletion in 7q21.11 (finding of this patient previously reported [24]) affecting the SEMA3A gene, which was inherited from the healthy father. While SEMA3A has not been described to be associated with human psychiatric disorders so far, the $16 \mathrm{p} 13.11$ deletion has previously been found to be associated with OCD [24] and with a variety of neurodevelopmental disorders, such as ASD, ID, epilepsy, and schizophrenia [46, 47], with reduced and male-biased penetrance [48]. Furthermore, a maternally inherited duplication overlapping the 16p13.11 was reported in an EO-OCD patient [26]. Therefore, the aforementioned findings support the possible causality of this aberration in OCD. 
We detected another variant in a recurrent CNV locus in a male patient with EO-OCD and comorbid tics, who carries a $437 \mathrm{~kb}$ duplication encompassing the region 1q21.1. The duplication was inherited from the mother and present in the sister, both according to the CYBOCS presenting sub-threshold OCD with similar phenotype including ordering behaviours. Notably, a duplication of that region has also been detected in a paediatric EO-OCD patient and his unaffected mother and dizygotic twin brother in the recently published cohort of Gazzellone et al. [26]. We, therefore, suggest that CNVs on the chromosome region 1q21.1, which have been reported to associate with congenital heart defects, developmental delay, ASD, and psychosis $[49,50]$, represent also a susceptibility locus for OCD. These phenotypes are subject to incomplete penetrance and variable expressivity, since in most of the cases they are inherited from apparently healthy parents [51].

We found several other smaller rare CNVs encompassing interesting candidate genes that have already been described in neurodevelopmental disorders, for which, however, additional evidence is needed to prove the possible relation with EO-OCD. One of these findings is the $258 \mathrm{~kb}$ duplication encompassing the gene GRM8, coding for a glutamate receptor, in 7q31.33, paternally inherited, observed in a female patient with EO-OCD and comorbid tics, but not in her sister with EO-OCD. CNVs encompassing the gene GRM8 have been reported in patients with attention-deficit hyperactivity disorder (ADHD) [52] and with developmental delay, hypotonia, and strabismus [20]. Recent evidence has highlighted the role of glutamatergic synaptic dysfunctions in the cortico-striatal-thalamo-cortical circuit in the aetiology of OCD and related disorders [9, 53, 54].

A further noteworthy CNV, $113 \mathrm{~kb}$ deletion encompassing the two genes GABRA4 and GABRB1 in 4p12, was found in a female patient of maternal origin that carried also a $66 \mathrm{~kb}$ duplication (EMILIN2 gene in 18p11.32). Involvement of GABA receptor subunit genes in the aetiology of autism has been reported [55-57]. Both GABRA4 and GABRB1 mRNA and protein were found to alter their expression in the parietal and frontal cortex and cerebellum of patients with ASD and in the lateral cerebellum of patients with schizophrenia and with affective disorders [58, 59]. In peripheral blood samples of patients with TS, mRNA expression of GABA receptors including $G A B R A 4$ correlated with tic severity. Furthermore, there was indication of GABRA4 being alternatively spliced in TS compared to healthy controls [60]. For the duplication, little is known about the EMILIN2 gene and neurodevelopment. However, patients carrying large deletions in $18 \mathrm{p} 11.32$ were reported to have developmental delay and mental retardation [61] while linkage study could show some evidence for schizophrenia susceptibility near this region [62].

A $279 \mathrm{~kb}$ deletion in $\mathrm{Xq11.2}$ encompassing the gene MTMR8 was found in a patient with EO-OCD as well as in his mother and brother, who both suffer from anxiety disorder. Anxiety is very often a core feature of OCD symptomatology and in the DSM-IV [27], OCD was even classified among the anxiety disorders, which shows the close relationship between the two diseases. MTMR8 encodes a phosphatidylinositol kinase and reduced protein expression is associated with impaired survival of specific neuronal populations [63]. Loss-of-function mutations occurring in the phosphatidylinositol kinase gene family are known to cause different X-linked neurological diseases, including schizophrenia, bipolar disorder and agerelated neurodegeneration, probably due to endosomal trafficking defects and accumulations of the lipid substrates $[64,65]$.

A de-novo deletion of $51 \mathrm{~kb}$ in $2 \mathrm{p} 16.3$ was detected in a male diagnosed with very EO-OCD (4 years old at age of onset) who suffered also from comorbid tics and hyperkinetic symptoms. The deletion encompasses the NRXN1 gene, for which an association with TS, ASD, ID, and schizophrenia has been described [24, 46, 66, 67]. Interestingly, the NRXN1- $\alpha$ knock-out mouse model supports the role of NRXN1 in neurodevelopmental disorders, since these mice displayed non-social behaviour as well as hyperactivity and learning deficits [68].

In another patient with comorbid tics we found a denovo deletion of $310 \mathrm{~kb}$ in 12q23.1 harbouring the genes $A N K S 1 B$ and UHRF1BP1 and a duplication of $80 \mathrm{~kb}$ in 19p13.11 harbouring the genes GMIP, ATP13A1, ZNF101 and ZNF14. ANKS1B is predominantly expressed in the brain and known to interact with the amyloid beta protein precursor that may play a role in normal brain development and in the pathogenesis of Alzheimer's disease $[69,70]$. CNVs affecting $A N K S 1 B$ have been reported in ASD and ID including a de-novo deletion in a male with ASD and delayed early language development but average language abilities and IQ [47, 71]. In addition, a $190 \mathrm{~kb}$ deletion encompassing the $A N K S 1 B$ gene was reported in a patient with EO-OCD [26], enhancing the possible role of the gene in neurodevelopmental disorders. Within the duplication, GMIP, coding for RhoA-specific GTPase-activating protein, was reported to be a key factor for neuronal migration in the postnatal brain [72] as well as regulating vesicular trafficking [73]. Moreover, in a large population-based twin-family study exploring genome-wide association of obsessive-compulsive symptoms, a significant association in 4 genes (MEF2BNB, RFXANK, MEF2BNB$M E F 2 B$ and $M E F 2 B$ ) located in proximity to GMIP gene was reported [74]. 


\section{Conclusions}

Our findings further support the role of rare CNVs in the aetiology of OCD and emphasize the role of rare small deletions encompassing brain genes as potential susceptibility factors in the aetiology of paediatric EOOCD. Further studies are necessary to confirm the contribution of the individual variants in OCD.

\section{Additional files}

Additional file 1: Table S1. Comorbidities according to ICD-10 of the pediatric OCD cohort. (DOCX $13 \mathrm{~kb}$ )

Additional file 2: Table S2a. Rare CNVs discovered in the paediatric obsessive compulsive disorder (OCD) patients; and inheritance pattern in cases with available parents. Table S2b. Rare CNVs discovered in the population control cohort. (PDF $236 \mathrm{~kb}$ )

Additional file 3: Table S3a. According to Pathway Studio. Table S3b. According to DAVID. (PDF $115 \mathrm{~kb}$ )

Additional file 4: Table S4. (a) CNV burden analysis results from PLINK The $p$-values shown are for the GCNT test statistic from PLINK's cnvenrichment-test algorithm, applied to the particular gene list versus the entire genome. Although Brain expressed and ID genes resulted in $p$ values below 0.05 , only the brain-expressed genes list remains significantly enriched in CNVs after correction for multiple testing (6 tests). (b) CNV burden analysis results from PLINK. The Gene List used. (PDF 1722 kb)

\section{Abbreviations}

ADHD: Attention-deficit hyperactivity disorder; ASD: Autism spectrum disorder; CMA: Chromosomal microarray analysis; CNV: Copy-number variation; CY-BOCS: Children's Yale Brown Obsessive Compulsive Scale; DAVID: Database for Annotation, Visualization and Integration Discovery; DGV: Database of Genomic Variants; EO: Early-onset; GEO: Gene Expression Omnibus; GO: Gene ontology; ID: Intellectual disability; IQ: Intelligence quotient; LO: Late-onset; OCD: Obsessive-compulsive disorder; OR: Odds ratio; SNPs: Single nucleotide polymorphisms; TS: Tourette syndrome

\section{Acknowledgments}

The authors thank the families, patients, and control volunteers who participated in this research. The authors would like to acknowledge Dr. Alexander Roth for his statistical analysis support, Prof. Dr. Soumya Raychaudhuri for providing us with the gene list files to be used in PLINK for the enrichment analysis, Ms. Miryame Hofmann and Dr. Regina Reissmann for their laboratory technical support and to Mr. Luca Sciancalepore for English editing support.

\section{Funding}

The study was funded by the University of Zurich.

\section{Availability of data and materials}

The datasets generated and/or analysed during the current study are not publicly available due to limits in consents but are available from the corresponding author on reasonable request.

\section{Authors' contributions \\ EG, BO, AR, SW contributed substantially to the conception and design of the study. EG, BO, ABE, JB, JG, SU, MR, AR, SW contributed substantially to the acquisition, analysis, and interpretation of data. All listed authors drafted the article and revised it critically for important intellectual content. Moreover, all authors gave their final approval of the version to be published. And all authors agree to be accountable for all aspects of the work in ensuring that questions related to the accuracy or integrity of any part of the work are appropriately investigated and resolved. All authors read and approved the final manuscript.}

\section{Ethics approval and consent to participate}

The study was approved by the respective local ethics committees with the latest version of the Declaration of Helsinki, including an ethical permission granted by the Ethic Committees from Würzburg and the Cantonal Ethic Commission of Zürich (Ref. Nr. 39/97, 140/3 and EK: KEK-ZH-Nr. 2010-0340/3) and written informed consent was obtained in all cases from the participants or/and their parents.

\section{Consent for publication}

Not applicable

\section{Competing interests}

The authors declare that they have no competing interests. SW has received lecture honoraria from Eli-Lily, Opopharma in the last 5 years. Outside professional activities and interests are declared, for AR and SW, under the link of the University of Zurich www.uzh.ch/prof/ssl-dir/interessenbindungen/client/ web/. However, the above did not affect the reporting in the current work.

\section{Publisher's Note}

Springer Nature remains neutral with regard to jurisdictional claims in published maps and institutional affiliations.

\section{Author details}

${ }^{1}$ Department of Child and Adolescent Psychiatry and Psychotherapy, University Hospital of Psychiatry Zurich, University of Zurich, Neumünsterallee 9, 8032 Zürich, Switzerland. ${ }^{2}$ Neuroscience Center Zurich, University of Zurich and ETH Zurich, Zurich, Switzerland. ${ }^{3}$ Department of Psychiatry, Psychosomatic and Psychotherapy, University Hospital of Würzburg, Würzburg, Germany. ${ }^{4}$ Zurich Center for Integrative Human Physiology, University of Zurich, Zurich, Switzerland. ${ }^{5}$ Institute of Medical Genetics, University of Zurich, Zurich-Schlieren, Switzerland. ${ }^{6}$ Center of Mental Health, Department of Child and Adolescent Psychiatry, Psychosomatics and Psychotherapy, University Hospital of Würzburg, Würzburg, Germany. ${ }^{7}$ Institute of Human Genetics, University Hospital Erlangen, Erlangen, Germany. ${ }^{8}$ Department of Child and Adolescent Psychiatry and Psychotherapy, University Hospital of Psychiatry Zurich, University of Zurich, Wagistrasse 12, 8952 Schlieren, Switzerland.

Received: 22 December 2016 Accepted: 6 November 2017

Published online: 28 November 2017

\section{References}

1. American Psychiatric Association. Diagnostic and statistical manual of mental disorders, fifth edition (DSM-5) $5^{\text {th }}$ edn. Washington DC: APA; 2013.

2. Ruscio AM, Stein DJ, Chiu WT, Kessler RC. The epidemiology of obsessivecompulsive disorder in the National Comorbidity Survey Replication. Mol Psychiatry. 2010;15(1):53-63.

3. Wittchen HU, Jacobi F, Rehm J, Gustavsson A, Svensson M, Jonsson B, Olesen J, Allgulander C, Alonso J, Faravelli C, et al. The size and burden of mental disorders and other disorders of the brain in Europe 2010. Eur Neuropsychopharmacol. 2011:21(9):655-79.

4. Flament MF, Whitaker A, Rapoport JL, Davies M, Berg CZ, Kalikow K, Sceery W, Shaffer D. Obsessive compulsive disorder in adolescence: an epidemiological study. J Am Acad Child Adolesc Psychiatry. 1988;27(6):764-71.

5. Delorme R, Golmard JL, Chabane N, Millet B, Krebs MO, Mouren-Simeoni MC, Leboyer M. Admixture analysis of age at onset in obsessive-compulsive disorder. Psychol Med. 2005;35(2):237-43.

6 Fontenelle LF, Mendlowicz MV, Marques C, Versiani M. Early- and late-onset obsessive-compulsive disorder in adult patients: an exploratory clinical and therapeutic study. J Psychiatr Res. 2003;37(2):127-33.

7. Taylor S. Early versus late onset obsessive-compulsive disorder: evidence for distinct subtypes. Clin Psychol Rev. 2011;31(7):1083-100.

8. Geller D, Biederman J, Jones J, Park K, Schwartz S, Shapiro S, Coffey B. Is juvenile obsessive-compulsive disorder a developmental subtype of the disorder? A review of the pediatric literature. J Am Acad Child Adolesc Psychiatry. 1998;37(4):420-7.

9. Pauls DL, Abramovitch A, Rauch SL, Geller DA. Obsessive-compulsive disorder: an integrative genetic and neurobiological perspective. Nat Rev Neurosci. 2014:15(6):410-24.

10. Mataix-Cols D, Boman M, Monzani B, Ruck C, Serlachius E, Langstrom N, Lichtenstein P. Population-based, multigenerational family clustering study of obsessive-compulsive disorder. JAMA Psychiat. 2013;70(7):709-17.

11. van Grootheest DS, Cath DC, Beekman AT, Boomsma DI. Twin studies on obsessive-compulsive disorder: a review. Twin Res Hum Genet. 2005;8(5):450-8. 
12. Stewart SE, Yu D, Scharf JM, Neale BM, Fagerness JA, Mathews CA, Arnold PD, Evans PD, Gamazon ER, Davis LK, et al. Genome-wide association study of obsessive-compulsive disorder. Mol Psychiatry. 2013;18(7):788-98.

13. Mattheisen M, Samuels JF, Wang Y, Greenberg BD, Fyer AJ, McCracken JT, Geller DA, Murphy DL, Knowles JA, Grados MA, et al. Genome-wide association study in obsessive-compulsive disorder: results from the OCGAS. Mol Psychiatry. 2014

14. Taylor S. Molecular genetics of obsessive-compulsive disorder: a comprehensive meta-analysis of genetic association studies. Mol Psychiatry. 2013;18(7):799-805.

15. XZ H, Lipsky RH, Zhu G, Akhtar LA, Taubman J, Greenberg BD, Xu K, Arnold $P D$, Richter MA, Kennedy JL, et al. Serotonin transporter promoter gain-offunction genotypes are linked to obsessive-compulsive disorder. Am J Hum Genet. 2006;78(5):815-26.

16. Walitza S, Marinova Z, Grünblatt E, Lazic SE, Remschmidt H, Vloet TD, Wendland JR. Trio study and meta-analysis support the association of genetic variation at the serotonin transporter with early-onset obsessivecompulsive disorder. Neurosci Lett. 2014;580:100-3.

17. Walitza S, Wewetzer C, Warnke A, Gerlach M, Geller F, Gerber G, Gorg T, Herpertz-Dahlmann B, Schulz E, Remschmidt H, et al. 5-HT2A promoter polymorphism -1438G/a in children and adolescents with obsessivecompulsive disorders. Mol Psychiatry. 2002;7(10):1054-7.

18. Kirov G. CNVs in neuropsychiatric disorders. Hum Mol Genet. 2015;24(R1):R45-9.

19. Torres F, Barbosa M, Maciel P. Recurrent copy number variations as risk factors for neurodevelopmental disorders: critical overview and analysis of clinical implications. J Med Genet. 2016:53(2):73-90.

20. Asadollahi R, Oneda B, Joset P, Azzarello-Burri S, Bartholdi D, Steindl K, Vincent M, Cobilanschi J, Sticht H, Baldinger R, et al. The clinical significance of small copy number variants in neurodevelopmental disorders. J Med Genet. 2014;51(10):677-88.

21. Gratten J, Wray NR, Keller MC, Visscher PM. Large-scale genomics unveils the genetic architecture of psychiatric disorders. Nat Neurosci. 2014;17(6):782-90.

22. Delorme R, Moreno-De-Luca D, Gennetier A, Maier W, Chaste P, Mossner R, Grabe HJ, Ruhrmann S, Falkai P, Mouren MC, et al. Search for copy number variants in chromosomes 15q11-q13 and 22q11.2 in obsessive compulsive disorder. BMC Med Genet. 2010;11:100.

23. Walitza S, Bove DS, Romanos M, Renner T, Held L, Simons M, Wewetzer C, Fleischhaker C, Remschmidt H, Warnke A, et al. Pilot study on HTR2A promoter polymorphism, -1438G/a (rs6311) and a nearby copy number variation showed association with onset and severity in early onset obsessive-compulsive disorder. J Neural Transm. 2012;119(4):507-15.

24. McGrath LM, Yu D, Marshall C, Davis LK, Thiruvahindrapuram B, Li B, Cappi C, Gerber G, Wolf A, Schroeder FA, et al. Copy number variation in obsessive-compulsive disorder and tourette syndrome: a cross-disorder study. J Am Acad Child Adolesc Psychiatry. 2014;53(8):910-9.

25. Cappi C, Hounie AG, Mariani DB, Diniz JB, Silva AR, Reis VN, Busso AF, Silva $A G$, Fidalgo F, Rogatto SR, et al. An inherited small microdeletion at $15 q 13.3$ in a patient with early- onset obsessive-compulsive disorder. PLoS One. 2014;9(10):e110198.

26. Gazzellone MJ, Zarrei M, Burton CL, Walker S, Uddin M, Shaheen SM, Coste J, Rajendram R, Schachter RJ, Colasanto M, et al. Uncovering obsessivecompulsive disorder risk genes in a pediatric cohort by high-resolution analysis of copy number variation. J Neurodev Disord. 2016;8:36.

27. American Psychiatric Association. DSM-IV. Diagnostic and statistical manual of mental disorders. 4th ed. Washington DC: APA; 1996.

28. Dilling $H$, Freyberger HJ, Stieglitz RD. ICD-10 field trial of the diagnostic criteria for research in German-speaking countries. Introduction. Psychopathology. 1996;29(5):258-9.

29. Unnewehr S, Schneider S, Margraf J. Kinder-DIPS: Diagnostisches Interview bei psychischen Störungen im Kindes- und Jugendalter. Berlin, Heidelberg, New York: Springer; 1995.

30. Kaufman J, Birmaher B, Brent D, Rao U, Flynn C, Moreci P, Williamson D, Ryan N. Schedule for affective disorders and schizophrenia for school-age childrenpresent and lifetime version (K-SADS-PL): initial reliability and validity data. J Am Acad Child Adolesc Psychiatry. 1997;36(7):980-8.

31. Döpfner M, Berner W, Flechtner $H$, Lehmkuhl G, Steinhausen $H$. Psychopathologisches Befundsystem für Kinder und Jugendliche (CASCAP-D). Göttingen: Hogrefe Verlag; 1999.

32. Scahill L, Riddle MA, McSwiggin-Hardin M, Ort SI, King RA, Goodman WK, Cicchetti D, Leckman JF. Children's Yale-Brown obsessive compulsive scale: reliability and validity. J Am Acad Child Adolesc Psychiatry. 1997;36(6):844-52.
33. Hebebrand J, Klug B, Fimmers R, Seuchter SA, Wettke-Schafer R, Deget F, Camps A, Lisch S, Hebebrand K, von Gontard A, et al. Rates for tic disorders and obsessive compulsive symptomatology in families of children and adolescents with Gilles de la Tourette syndrome. J Psychiatr Res. 1997;31(5):519-30.

34. Pauls DL, Raymond CL, Stevenson JM, Leckman JF. A family study of Gilles de la Tourette syndrome. Am J Hum Genet. 1991:48(1):154-63.

35. Leckman JF, Riddle MA, Hardin MT, Ort SI, Swartz KL, Stevenson J, Cohen DJ. The Yale global tic severity scale: initial testing of a clinician-rated scale of tic severity. J Am Acad Child Adolesc Psychiatry. 1989;28(4):566-73.

36. Petermann F, Petermann U, editors. WISC-iv. Frankfurt am Main: Pearson Assesment; 2011.

37. Wiess R, editor. Grundintelligenztest Skala-2 Revision- (CFT-20R). Göttingen: Hogrefe; 2006

38. Miller SA, Dykes DD, Polesky HF. A simple salting out procedure for extracting DNA from human nucleated cells. Nucleic Acids Res. 1988;16(3):1215.

39. Faul F, Erdfelder E, Buchner A, Lang AG. Statistical power analyses using G*power 3.1: tests for correlation and regression analyses. Behav Res Methods. 2009:41(4):1149-60

40. Subramanian A, Tamayo P, Mootha VK, Mukherjee S, Ebert BL, Gillette MA Paulovich A, Pomeroy SL, Golub TR, Lander ES, et al. Gene set enrichment analysis: a knowledge-based approach for interpreting genome-wide expression profiles. Proc Natl Acad Sci U S A. 2005;102(43):15545-50.

41. Mootha VK, Lindgren CM, Eriksson KF, Subramanian A, Sihag S, Lehar J, Puigserver P, Carlsson E, Ridderstrale M, Laurila E, et al. PGC-1alpharesponsive genes involved in oxidative phosphorylation are coordinately downregulated in human diabetes. Nat Genet. 2003;34(3):267-73.

42. Huang d W, Sherman BT, Lempicki RA. Systematic and integrative analysis of large gene lists using DAVID bioinformatics resources. Nat Protoc. 2009; 4(1):44-57.

43. Purcell S, Neale B, Todd-Brown K, Thomas L, Ferreira MA, Bender D, Maller J, Sklar $P$, de Bakker PI, Daly MJ, et al. PLINK: a tool set for whole-genome association and population-based linkage analyses. Am J Hum Genet. 2007;81(3):559-75.

44. Raychaudhuri S, Korn JM, McCarroll SA, International Schizophrenia C, Altshuler D, Sklar P, Purcell S, Daly MJ. Accurately assessing the risk of schizophrenia conferred by rare copy-number variation affecting genes with brain function. PLoS Genet. 2010;6(9):e1001097.

45. Yu D, Mathews CA, Scharf JM, Neale BM, Davis LK, Gamazon ER, Derks EM, Evans $\mathrm{P}$, Edlund CK, Crane J, et al. Cross-disorder genome-wide analyses suggest a complex genetic relationship between Tourette's syndrome and OCD. Am J Psychiatry. 2015;172(1):82-93.

46. Grayton HM, Fernandes C, Rujescu D, Collier DA. Copy number variations in neurodevelopmental disorders. Prog Neurobiol. 2012;99(1):81-91.

47. Abrahams BS, Arking DE, Campbell DB, Mefford HC, Morrow EM, Weiss LA, Menashe I, Wadkins T, Banerjee-Basu S, Packer A. SFARI gene 2.0: a community-driven knowledgebase for the autism spectrum disorders (ASDs). Molecular autism. 2013:4(1):36.

48. Tropeano M, Ahn JW, Dobson RJ, Breen G, Rucker J, Dixit A, Pal DK, McGuffin P, Farmer A, White PS, et al. Male-biased autosomal effect of 16p13.11 copy number variation in neurodevelopmental disorders. PLoS One. 2013;8(4):e61365.

49. Dolcetti A, Silversides CK, Marshall CR, Lionel AC, Stavropoulos DJ, Scherer SW, Bassett AS. 1q21.1 microduplication expression in adults. Genet Med. 2013;15(4):282-9.

50. Bernier R, Steinman K, Reilly B, Wallace AS, Sherr EH, Pojman N, Mefford HC, Gerdts J, Earl R, Hanson E, et al. Clinical phenotype of the recurrent 1q21.1 copy-number variant. Genet Med. 2016;18(4):341-9.

51. Brunetti-Pierri N, Berg JS, Scaglia F, Belmont J, Bacino CA, Sahoo T, Lalani SR, Graham B, Lee B, Shinawi M, et al. Recurrent reciprocal 1q21.1 deletions and duplications associated with microcephaly or macrocephaly and developmental and behavioral abnormalities. Nat Genet. 2008;40(12):1466-71.

52. Elia J, Glessner JT, Wang K, Takahashi N, Shtir CJ, Hadley D, Sleiman PM, Zhang H, Kim CE, Robison R, et al. Genome-wide copy number variation study associates metabotropic glutamate receptor gene networks with attention deficit hyperactivity disorder. Nat Genet. 2011; 44(1):78-84

53. Brem S, Grünblatt E, Drechsler R, Riederer P, Walitza S. The neurobiological link between OCD and ADHD. Attention deficit and hyperactivity disorders. 2014:6(3):175-202.

54. Grünblatt E, Hauser TU, Walitza S. Imaging genetics in obsessive-compulsive disorder: linking genetic variations to alterations in neuroimaging. Prog Neurobiol. 2014;121:114-24. 
55. Kakinuma $H$, Ozaki M, Sato $H$, Takahashi $H$. Variation in GABA-A subunit gene copy number in an autistic patient with mosaic $4 \mathrm{p}$ duplication (p12p16). Am J Med Genet B Neuropsychiatr Genet. 2008;147B(6):973-5.

56. Ma DQ, Whitehead PL, Menold MM, Martin ER, Ashley-Koch AE, Mei $\mathrm{H}$, Ritchie MD, Delong GR, Abramson RK, Wright HH, et al. Identification of significant association and gene-gene interaction of GABA receptor subunit genes in autism. Am J Hum Genet. 2005;77(3): 377-88.

57. Collins AL, Ma D, Whitehead PL, Martin ER, Wright HH, Abramson RK, Hussman JP, Haines JL, Cuccaro ML, Gilbert JR, et al. Investigation of autism and GABA receptor subunit genes in multiple ethnic groups. Neurogenetics. 2006;7(3):167-74.

58. Fatemi SH, Reutiman TJ, Folsom TD, Rooney RJ, Patel DH, Thuras PD. mRNA and protein levels for GABAAalpha4, alpha5, beta1 and GABABR1 receptors are altered in brains from subjects with autism. J Autism Dev Disord. 2010;40(6):743-50.

59. Fatemi SH, Folsom TD, Rooney RJ, Thuras PD. Expression of GABAA alpha2-, beta1- and epsilon-receptors are altered significantly in the lateral cerebellum of subjects with schizophrenia, major depression and bipolar disorder. Transl Psychiatry. 2013;3:e303.

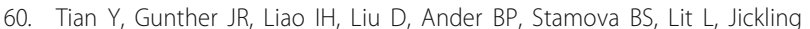
GC, Xu H, Zhan X, et al. GABA- and acetylcholine-related gene expression in blood correlate with tic severity and microarray evidence for alternative splicing in Tourette syndrome: a pilot study. Brain Res. 2011;1381:228-36.

61. Moog U, Engelen JJ, de Die-Smulders CE, Albrechts JC, Loneus WH, Haagen AA, Raven EJ, Hamers AJ. Partial trisomy of the short arm of chromosome 18 due to inversion duplication and direct duplication. Clin Genet. 1994;46(6):423-9.

62. Faraone SV, Skol AD, Tsuang DW, Young KA, Haverstock SL, Prabhudesai $S$, Mena F, Menon AS, Leong L, Sautter F, et al. Genome scan of schizophrenia families in a large veterans affairs cooperative study sample: evidence for linkage to $18 \mathrm{p} 11.32$ and for racial heterogeneity on chromosomes 6 and 14. Am J Med Genet B Neuropsychiatr Genet. 2005;139B(1):91-100.

63. Zou J, Zhang C, Marjanovic J, Kisseleva MV, Majerus PW, Wilson MP. Myotubularin-related protein (MTMR) 9 determines the enzymatic activity, substrate specificity, and role in autophagy of MTMR8. Proc Natl Acad Sci U S A. 2012;109(24):9539-44.

64. Clayton EL, Minogue S, Waugh MG. Phosphatidylinositol 4-kinases and PI4P metabolism in the nervous system: roles in psychiatric and neurological diseases. Mol Neurobiol. 2013;47(1):361-72.

65. Holman SK, Morgan T, Baujat G, Cormier-Daire V, Cho TJ, Lees M, Samanich J, Tapon D, Hove HD, Hing A, et al. Osteopathia striata congenita with cranial sclerosis and intellectual disability due to contiguous gene deletions involving the WTX locus. Clin Genet. 2013; 83(3):251-6.

66. Dabell MP, Rosenfeld JA, Bader P, Escobar LF, El-Khechen D, Vallee SE, Dinulos MB, Curry C, Fisher J, Tervo R, et al. Investigation of NRXN1 deletions: clinical and molecular characterization. Am J Med Genet A. 2013; 161A(4):717-31.

67. Nag A, Bochukova EG, Kremeyer B, Campbell DD, Muller $H$, ValenciaDuarte AV, Cardona J, Rivas IC, Mesa SC, Cuartas M, et al. CNV analysis in Tourette syndrome implicates large genomic rearrangements in COL8A1 and NRXN1. PLoS One. 2013;8(3):e59061.

68. Esclassan F, Francois J, Phillips KG, Loomis S, Gilmour G. Phenotypic characterization of nonsocial behavioral impairment in Neurexin 1alpha knockout rats. Behav Neurosci. 2014;

69. Smirnova E, Shanbhag R, Kurabi A, Mobli M, Kwan JJ, Donaldson LW. Solution structure and peptide binding of the PTB domain from the AIDA1 postsynaptic signaling scaffolding protein. PLoS One. 2013;8(6): e65605.

70. Ghersi E, Vito P, Lopez P, Abdallah M, D'Adamio L. The intracellular localization of amyloid beta protein precursor (AbetaPP) intracellular domain associated protein-1 (AIDA-1) is regulated by AbetaPP and alternative splicing. Journal of Alzheimer's disease : JAD. 2004;6(1):67-78.

71. Pinto D, Pagnamenta AT, Klei L, Anney R, Merico D, Regan R, Conroy J, Magalhaes TR, Correia C, Abrahams BS, et al. Functional impact of global rare copy number variation in autism spectrum disorders. Nature. 2010;466(7304):368-72.
72. Ota H, Hikita T, Sawada M, Nishioka T, Matsumoto M, Komura M, Ohno A, Kamiya Y, Miyamoto T, Asai N, et al. Speed control for neuronal migration in the postnatal brain by Gmip-mediated local inactivation of RhoA. Nat Commun. 2014:5:4532.

73. Johnson JL, Monfregola J, Napolitano G, Kiosses WB, Catz SD. Vesicular trafficking through cortical actin during exocytosis is regulated by the Rab27a effector JFC1/SIp1 and the RhoA-GTPase-activating protein geminteracting protein. Mol Biol Cell. 2012;23(10):1902-16.

74. den Braber A, Zilhao NR, Fedko IO, Hottenga JJ, Pool R, Smit DJ, Cath DC, Boomsma DI: Obsessive-compulsive symptoms in a large population-based twin-family sample are predicted by clinically based polygenic scores and by genome-wide SNPs. Transl Psychiatry 2016, 6:e731.

\section{Submit your next manuscript to BioMed Central and we will help you at every step:}

- We accept pre-submission inquiries

- Our selector tool helps you to find the most relevant journal

- We provide round the clock customer support

- Convenient online submission

- Thorough peer review

- Inclusion in PubMed and all major indexing services

- Maximum visibility for your research

Submit your manuscript at www.biomedcentral.com/submit
C Biomed Central 